\title{
Effect of Prenatal Stress on Expression of Glutathione System in Neonatal Rat Brain
}

\section{Prenatal Stresin Neonatal Suçan Beyninde Glutatyon Sistemi Ekspresyonuna Etkisi}

\author{
Sudhanshu SAHU ${ }^{1}$, Sampath MADHYASTHA ${ }^{1}$, Gayathri RAO ${ }^{2}$ \\ ${ }^{1}$ Manipal University, Kasturba Medical College, Department of Anatomy, Mangalore, India \\ ${ }^{2}$ Manipal University, Kasturba Medical College, Department of Biochemistry, Mangalore, India
}

Correspondence address: Sampath MADHYASTHA / E-mail: sampath.m@manipal.edu, madhyast@yahoo.com

\begin{abstract}
AIM: Prenatal stress is known to adversely affect the fetal brain development and also neuronal loss. The mechanism(s) associated with prenatal stress induced developmental neurotoxicity remains obscure. Few studies point to the glutathione (GSH) antioxidant system which is an important molecular target for this toxicant. Hence the present study investigates the effect of prenatal stress on glutathione system in neonatal rat brain.

MATERIAL and METHODS: Three to four months old pregnant Wistar rats were subjected to restraint stress during early or late gestational period. The offspring were sacrificed on 40th day and their brain homogenate was subjected to antioxidant studies. The serum corticosterone and adrenal ascorbic acid levels were also estimated from offspring.

RESULTS: The prenatal stress has resulted in an increase in the serum corticosterone and reduced adrenal ascorbic acid levels in neonatal pups. Prenatal stress during early or late gestation life showed reduced glutathione, glutathione reductase (GSSG-Rd) and superoxide dismutase (SOD) activity in offspring brain homogenate.

CONCLUSION: These data suggest that stress during early or late gestation period affect glutathione system in developing neonatal rat brain, which is associated with elevated serum corticosterone and reduced adrenal ascorbic acid levels.
\end{abstract}

KEYWORDS: Prenatal stress, Glutathione, Glutathione reductase, Superoxide dismutase, Antioxidant enzymes

öz

AMAÇ: Prenatal stresin fetal beyin gelişimi ve ayrıca nöron kaybını olumsuz şekilde etkilediği bilinmektedir. Prenatal stres tarafından indüklenen gelişimsel nörotoksisiteyle ilişkili mekanizma(lar) halen bilinmemektedir. Birkaç çalışma bu toksik madde için önemli bir moleküler hedef olan glutatyon (GSH) antioksidan sistemine işaret etmektedir. Bu nedenle bu çalışma neonatal sıçan beyninde prenatal stresin glutatyon sistemi üzerine etkisini incelemektedir.

YÖNTEM ve GEREÇLER: Üç ila dört aylık hamile Wistar sıçanları erken veya geç gestasyonel dönemde zaptetme stresine maruz bırakıldı. Yavrular 40. günde sakrifiye edildi ve beyin homojenatları antioksidan çalışmalara tabi tutuldu. Ayrıca yavrularda serum kortikosteron ve adrenal askorbik asit düzeyleri saptandı.

BULGULAR: Prenatal stres neonatal sıçanlarda artmış serum kortikosteron ve azalmış adrenal askorbik asit düzeylerine neden oldu. Erken veya geç gestasyonda prenatal stres, yavruların beyin homojenatında azalmış glutatyon, glutatyon redüktaz (GSSG-Rd) ve süperoksit dismutaz (SOD) aktivitesine neden oldu.

SONUÇ: Bu veriler erken veya geç gestasyon döneminde stresin gelişen neonatal sıçan beyninde glutatyon sistemini etkilediği ve sonuçta artmış serum kortikosteron ve azalmış adrenal askorbik asit düzeyleriyle ilişkili olduğunu düşündürmektedir.

ANAHTAR SÖZCÜKLER: Prenatal stres, Glutatyon, Glutatyon redüktaz, Süperoksit dismutaz, Antioksidan enzimler

\section{INTRODUCTION}

A substantial body of evidence indicates that prenatal stress adversely affects the brain development with neuronal loss and cognitive dysfunction. There are reports suggesting the possible mechanisms like increased brain corticosterone level (27), altered hypothalamo-pituitary-adrenal (HPA) axis (14), altered neurotransmitters (10) and the altered cellular homeostasis by oxidative damage (10) in brain which in turn involves neuronal death. Though the mechanisms involved in prenatal stress induced neuronal damage is not clearly understood, we hypothesized that the defective antioxidant system in the developing rat brain could be the cause, since brain is particularly vulnerable to oxidative stress due to its high rate of oxygen consumption. Though neurons are endowed with defense and repair mechanism to override the oxidative stress but existence of such defensive system in developing brain is obscure. 
A number of studies suggest that prenatal stress is associated with alterations in the offspring HPA axis activity. Some studies find prenatal stress to be associated with higher basal glucocorticoid (GC) secretion. For example, baseline corticosterone release is elevated in rat pups whose mothers were stressed during gestation $(12,15,27,29)$ or when stress hormones were administered to the mothers during pregnancy (7). Prenatal stress during the last week of pregnancy resulted in $64 \%$ increase in the level of plasma corticosterone in the offspring (27).

Enhanced plasma corticosterone level due to prenatal stress has a major impact on the developing brain (28). The possible involvement of oxidants and the relation to GC hormones in stress has been proposed $(11,18)$. Enhanced GC inhibits glucose utilization, thereby compromising the activity of energy-dependent excitatory amino acid transporters. The ensuing increase in glutamate concentrations results in excessive stimulation of postsynaptic excitatory amino acid receptors and unregulated increase in intracellular $\mathrm{Ca}^{2+}$ concentrations. Consequently, $\mathrm{Ca}^{2+}$ dependent endonucleases and other $\mathrm{Ca}^{2+}$ dependent enzymes that contribute to the production of reactive oxygen species (ROS) are activated. In addition, mitochondrial respiration is compromised by overload of calcium and other GC-mediated effects, further contributing to ROS production. This could be the one of the factor associated with the cellular damage. Hence the cellular damage in the developing brain could be attributed to over production of oxidants. Hence the present study is focused to evaluate the antioxidant defense system in neonatal rat brain and also looking at possible role of fetal serum corticosterone.

\section{MATERIAL and METHODS}

\section{Animals and housing conditions:}

In-house bred male and female albino Wistar rats (3-4 months old) of weight $200-230 \mathrm{gm}$ were selected for the study. The rats were maintained in 12 hours light and dark cycle in temperature and humidity controlled environment. The rats were fed with standard food pellet and water ad libitum. Polypropylene cage with paddy husk as bedding materials was used for housing the rats. Breeding and maintenance of the animals were done as per the guidelines of Government of India for use of Laboratory animals (Government of India notifies the rules for breeding and conducting animal experiments, proposed in the gazette of India Dec 15, 1998: which was reproduced in Ind. Journal of Pharmacol 31:9295, 1999). Institutional Animal Ethics Committee (I.A.E.C) approval was obtained before the conduct of the study (IAEC/ $\mathrm{KMC} / 11 / 06 / 2010)$ and care was taken to handle the rats in humane manner.

\section{Mating of rats and animal groups:}

Female rats were allowed to mate with one fertile sexually active male for four hours per day (separate male rats for each group). At the end of four hours, female rats were separated and vaginal smears taken to detect the presence of sperm for the confirmation of pregnancy and the rats were designated as day 0 of pregnancy for further counting the days. The pregnant rats were housed individually in separate cages with proper label indicating the day of conception and randomly allocated into three groups of six each. One male and one female pup from each mother (a total of 12 pups in each group) were considered for antioxidant studies.

\section{Stressing procedure}

The pregnant rats were stressed (restraint stress) using a wire mesh restrainer (23) for three times daily for $45 \mathrm{~min}$. The wire mesh restrainer will have a wooden base and stainless steel wire mesh restrainer hinged to the base. A pad lock and latch will help to secure the rat in the restrainer. The restrainer with dimension $11 \mathrm{~cm} \mathrm{(L)} \times 6 \mathrm{~cm}(\mathrm{~B}) \times 6 \mathrm{~cm}(\mathrm{H})$ was used for rats with gestation day 1 to 10 . Restrainer of $11 \mathrm{~cm}(\mathrm{~L}) \times 8 \mathrm{~cm}(\mathrm{~B}) \times 8$ $\mathrm{cm}(\mathrm{H})$ was used for rats with gestation day 11 to till delivery. This type of restrainer will only restrict the animal movement without any pain, discomfort or suffocation.

\section{Animal groups}

Group 1 (Control). The pups belonging to the pregnant rats who received only $0.5 \%$ carboxy methyl cellulose in a dose of $10 \mathrm{ml} / \mathrm{kg}$ body weight (oral) throughout pregnancy.

Group 2. The pups belonging to the pregnant rats who received restrain stress from gestation day 1 to 10 .

Group 3. The pups belonging to the pregnant rats who received restrain stress from gestation day 11 to till delivery.

All the mothers delivered at term (22-24 $4^{\text {th }}$ day of gestation). The offspring of the all groups were raised by their biological mothers until weaning ( $21^{\text {st }}$ day after birth).

\section{Chemicals}

All chemicals and reagents are HPLC or analytical grade (Sigma, St. Louis, Mo, U.S.A.) procured from Sri Durga laboratories, Mangalore, India.

\section{Experimental design:}

At the $40^{\text {th }}$ postnatal day one male and one female pups from each mother $(n=12)$ were weighed and sacrificed by decapitation after obtaining blood sample under ether anesthesia. The whole brain was removed rapidly and rinsed with sucrose isotonic buffer. Tissue was weighed and homogenized $(1: 10 \mathrm{w} / \mathrm{v})$ in sucrose isotonic buffer $(0.32 \mathrm{mM}$ sucrose, $12.5 \mathrm{mMTris}$ and $1 \mathrm{mM}$ EDTA), $\mathrm{pH} 7.4$ and dilution $1: 19$. The homogenate was centrifuged at $10,000 \mathrm{~g}$ for $20 \mathrm{~min}$ at $4^{\circ} \mathrm{C}$ and aliquots of supernatant were separated and used for following biochemical estimations. Adrenal gland was removed and $10 \%(\mathrm{w} / \mathrm{v})$ tissue homogenate was prepared in ice-cold $0.1 \mathrm{M}$ saline phosphate buffer ( $\mathrm{pH} 7.4)$, centrifuged for $15 \mathrm{~min} 10,000 \mathrm{~g}$ at $4^{\circ} \mathrm{C}$ and the supernatant was used for estimation of adrenal ascorbic acid.

\section{Quantification of corticosterone concentrations in blood serum:}

Blood samples were taken between 8.00 and 10.00 AM 
to avoid circadian variations of serum corticosterone concentrations. The animals were anesthetized individually in a glass jar containing saturated ether vapour and intracardiac blood was collected. Corticosterone was measured by using electro chemiluminescent method using an ECOBAS 411 automatic analyzer (Roche Diagnostics, U.S.A.) established at the Kasturba Medical College Laboratory, Mangalore, India. The concentration of corticosterone was expressed in $\mathrm{ng} / \mathrm{ml}$ serum.

\section{Adrenal gland weight and estimation of adrenal ascorbic acid:}

The abdominal cavity was opened and the adrenal glands were recovered, carefully freed from adjacent tissues under a stereo dissecting microscope, and weighed individually by using high precision single pan electronic weighing balance (Adventure $^{\mathrm{TM}}$ ).

Adrenal ascorbic acid was measured as described previously by Lyle et al. (20). In the adrenal gland homogenate, $6 \%$ Tricaboxylic acid (TCA) was added and centrifuged at $3000 \mathrm{~g}$ for $15 \mathrm{~min}$. The supernatant was coupled with $2,4, \mathrm{~N}$-dinitrophenyl hydrazine (DNPH) in presence of thiourea as a mild reducing agent. $2 \mathrm{ml}$ cold conc. $\mathrm{H}_{2} \mathrm{SO}_{4}(12 \mathrm{M})$ was added drop by drop, which converts DNPH into a red compound, which was assayed spectrophotometrically with a Systronic-117 UV-Visible spectrophotometer at 520nm. The value was expressed in $\mu \mathrm{g} / \mathrm{mg}$ protein. Protein was measured using the Lowery's method (13).

\section{Estimation of reduced Glutathione:}

Tissue GSH concentration was estimated according to the method described by Ellman (6). One $\mathrm{ml}$ of supernatant was precipitated with $1 \mathrm{ml}$ of metaphosphoric acid and cold digested at $4^{\circ} \mathrm{C}$ for $1 \mathrm{~h}$. The samples were centrifuged at $1,200 \mathrm{~g}$ for $15 \mathrm{~min}$ at $4^{\circ} \mathrm{C}$. To $1 \mathrm{ml}$ of this supernatant, $2.7 \mathrm{ml}$ of phosphate buffer and $0.2 \mathrm{ml}$ of 5, 5' dithio-bis (2-nitrobenzoic acid, DTNB) was added. The yellow color that developed was read immediately at $412 \mathrm{~nm}$ using a Systronic- 117 spectrophotometer. The values were expressed in $\mathrm{mg} /$ gm protein. The total protein concentration of tissues was measured by the method of Lowry et al. (13).

\section{Assay of Glutathione Reductase:}

The GSSG-Rd activity was measured using the method originally described by Moron et al. (19). The reaction mixture consisted of $1.6 \mathrm{ml}$ of $0.067 \mathrm{M}$ potassium phosphate buffer $(\mathrm{pH}$ 6.6), $0.12 \mathrm{ml}$ of $0.06 \% \mathrm{NADPH}, 0.12 \mathrm{ml} 1.15 \%$ GSSG, $0.1 \mathrm{ml}$ of enzyme source and water in a final volume of $2 \mathrm{ml}$. All mixtures and solutions were prepared at room temperature. Control cuvettes then received $180 \mu \mathrm{L}$ of deionised water while sample cuvettes received $60 \mu \mathrm{L}$ of deionised water and 120 $\mu \mathrm{L}$ of GSSG solution. NADPH oxidation was followed for $5 \mathrm{~min}$ and was recorded using a Systronic-117 spectrophotometer. The reduction of GSSG to GSH was determined indirectly by the measurement of the consumption of $\mathrm{NADPH}$, as demonstrated by a decrease in absorbance at $340 \mathrm{~nm}$ as a function of time. The enzyme activity was calculated using extinction coefficient of chromophore $\left(1.36 \times 10^{4}(\mathrm{~mol} / \mathrm{l})^{-1} \mathrm{~cm}^{-}\right.$ 1) and expressed as nmol NADPH oxidized $/ \mathrm{min} / \mathrm{mg}$ protein. Protein content was determined by the method of Lowry et al. (13) with bovine serum albumin as standard.

\section{Assay of Superoxide Dismutase activity:}

Superoxide dismutase (SOD) activity was determined by the method of Marklund et al. (17). The reaction was performed in an mixture containing $5.6 \times 10^{-5} \mathrm{M}$ nitrobluetetrazolium (NBT), $1.17 \times 10^{-6} \mathrm{M}$ riboflavin, $1 \times 10^{-2} \mathrm{M}$ methionine in $0.05 \mathrm{M}$ potassium phosphate buffer, $\mathrm{pH} 7.8$ with suitably diluted tissue homogenate in a total volume of $3 \mathrm{ml}$. Illumination of solution was carried out in an aluminum lined foil box fitted with an $15 \mathrm{v}$ fluorescent lamp. The solution taken in a beaker was kept in the box and illuminated exactly for $10 \mathrm{~min}$. Control without the enzyme source was prepared. The absorbance was measured spectrophotometrically with a Systronic-117 UV-Visible spectrophotometer at $560 \mathrm{~nm}$. SOD activity was expressed as specific activity of the enzyme in units per $\mathrm{mg}$ protein (U/mg protein). Protein content was determined by the method of Lowry et al (13).

\section{Statistical analysis:}

All the values were expressed as mean $\pm \mathrm{SE}$. The significance of differences among the groups was assessed using one way analysis of Variance (ANOVA) test followed by Bonferroni's multiple comparison test. Comparison of data between male and female group was assessed by unpaired " $t$ " test. $P$ values $<0.05$ were considered as significant.

\section{RESULTS}

Gestational period stress did not had significant effect on gestational length $(p=0.077, F=2.231)$ and litter size $(p=0.689$, $\mathrm{F}=0.614$ ). There was absolute no mortality in any of the group till $21^{\text {st }}$ postnatal day (Table I).

There was no sexually dimorphic effect in all the parameters studied, hence mean values for both male and female were collapsed. Early and late gestational stress did not show any difference in any parameters studied, as there is no statistical significant difference was observed between group- 2 and group-3.

\section{Effect of prenatal stress on basal corticosterone levels in the offspring}

A significant increase in serum corticosterone level in the offspring of stressed mothers \{group-2 $(p<0.01)$ and group-3 $(p<0.001)\}$ compared to control rat pups (group-1) (Figure 1).

Table I: Effect of Prenatal Stress on Gestational Length and Litter Size

\begin{tabular}{|l|c|c|}
\hline & Gestational length (days) & Litter size \\
\hline Group-1 & $22.83 \pm 0.16$ & $6.83 \pm 0.60$ \\
\hline Group-2 & $23.33 \pm 0.21$ & $7.33 \pm 0.55$ \\
\hline Group-3 & $22.50 \pm 0.22$ & $7.16 \pm 0.47$ \\
\hline
\end{tabular}




\section{Effect of prenatal stress on adrenal weight and adrenal ascorbic acid in the offspring}

Immobilization stress during early or late gestation did not had significant effect on adrenal gland weight $(p=0.942$, $\mathrm{F}=0.242$ ). The mean adrenal gland weight for group-1 was $8.57 \pm 0.30$, for group $-2,8.55 \pm 0.35$ and for group-3, 8.42 \pm 0.39 mg respectively.

Adrenal ascorbic acid was significantly deleted in prenatally stressed offspring \{group-2 $(p<0.001)$ and group-3 $(p<0.01)$ \} compared to non-stressed control rat pups (group-1) (Figure 2).

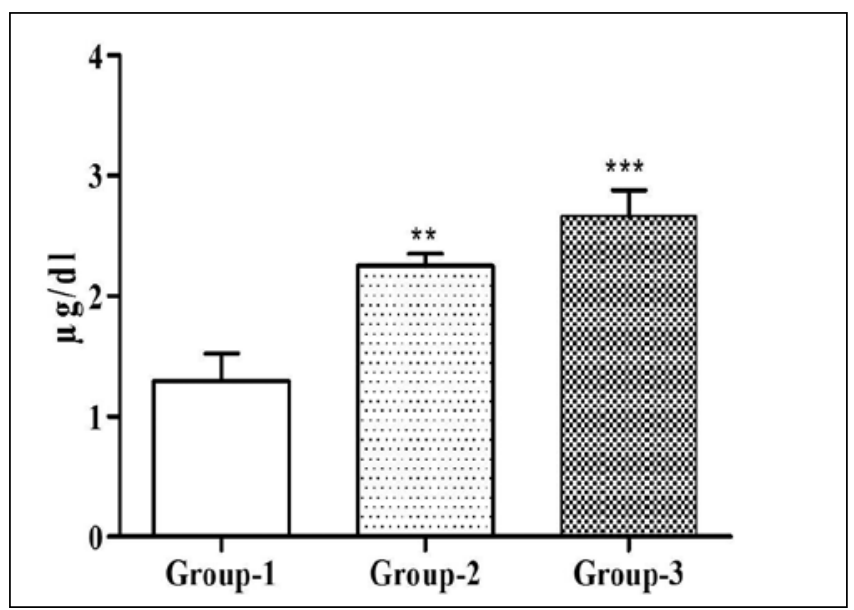

Figure 1: Serum Corticosterone level $(\mu \mathrm{g} / \mathrm{dl})$ in rats. Values represent Mean \pm SEM from animal groups like; Group-1: control, Group-2: pups received prenatal stress during day 1 to 10 and Group-3: pups received stress during day 11 till delivery $(\mathrm{n}=12$ per group). ${ }^{* *} \mathrm{P}<0.001,{ }^{* *} \mathrm{P}<0.01$ vs. Control (Group-1).

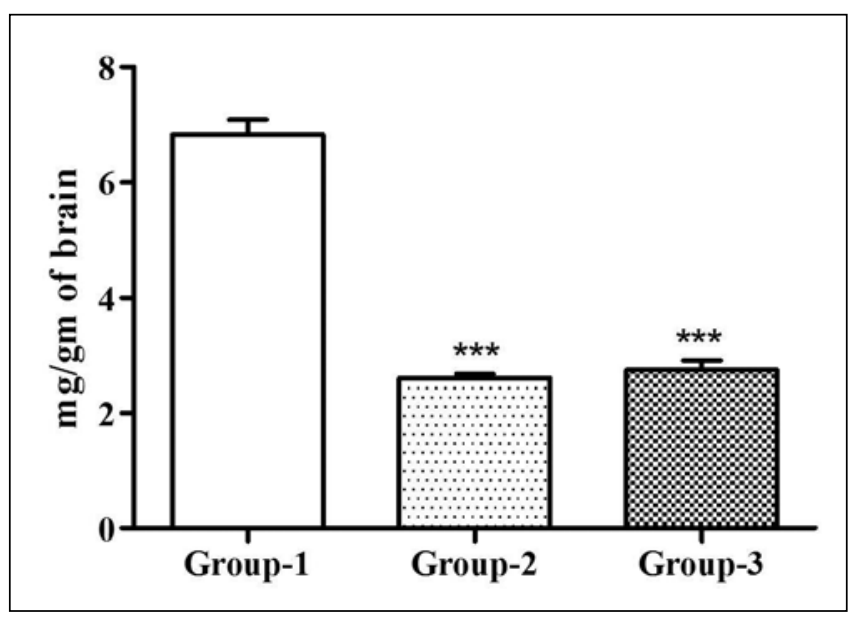

Figure 3: Brain reduced glutathione level ( $\mathrm{mg} / \mathrm{gm}$ protein) in rats. Values represent Mean \pm SEM from animal groups like; Group-1: control, Group-2: pups received prenatal stress during day1 to 10 and Group-3: pups received stress during day 11 till delivery ( $n=12$ per group). ${ }^{* * *} \mathrm{P}<0.001$ vs. Control (Group-1).

\section{Effect of prenatal stress in the levels of reduced glutathione (GSH) in the brain of offspring}

Prenatal stress (early as well as late gestation period) caused a significant $(p<0.001)$ depletion of GSH level in the brain homogenate (group-2 and group-3) compared to control (group-1). This clearly indicates that prenatal stress during early as well as late gestational period causes oxidative damage in the offspring brain (Figure 3 ).

Effect of prenatal stress in glutathione reductase (GSH$R d)$ activity in the brain

The activity of brain GSH-Rd was significantly $(p<0.001)$ decreased in prenatally stressed rat pups (group-2 and group-3) compared to control offspring (group-1) (Figure 4).

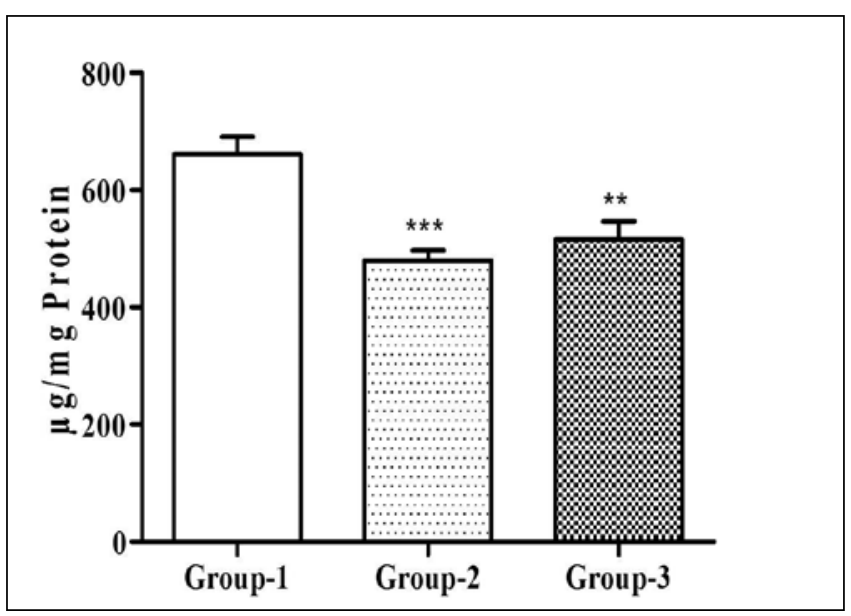

Figure 2: Adrenal ascorbic acid level ( $\mu \mathrm{g} / \mathrm{mg}$ Protein) in rats. Values represent Mean \pm SEM from animal groups like; Group-1: control, Group-2: pups received prenatal stress during day 1 to 10 and Group-3: pups received stress during day 11 till delivery ( $n=12$ per group). ${ }^{* *} \mathrm{P}<0.001,{ }^{* *} \mathrm{P}<0.01$ vs. Control (Group- 1 ).

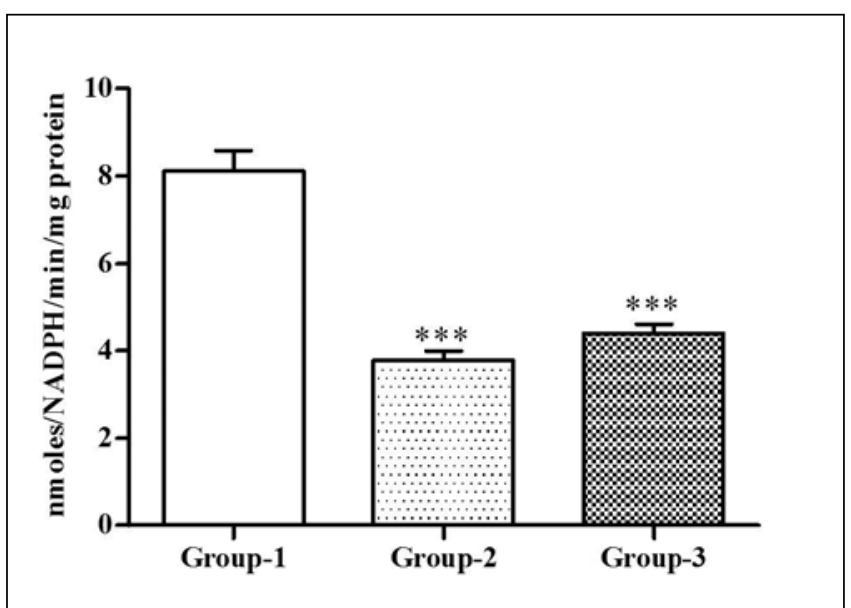

Figure 4: Brain Glutathione reductase activity (nmol NADPH oxidized $/ \mathrm{min} / \mathrm{mg}$ protein) in rats. Values represent Mean \pm SEM from animal groups like; Group-1: control, Group-2: pups received prenatal stress during day 1 to 10 and Group-3: pups received stress during day 11 till delivery ( $n=12$ per group). ${ }^{* *} \mathrm{P}$ $<0.001$ vs. Control (Group-1). 


\section{Effect of prenatal stress in Superoxide dismutase (SOD) activity in the brain}

The brain SOD activity was also decreased significantly in group-2 $(p<0.01)$ and group-3 $(p<0.001)$ when compared with control pups (group-1) (Figure 5) (Table II).

\section{DISCUSSION}

Antioxidant system is an important protective mechanism against ROS and, like many other biochemical systems; their effectiveness may vary with the stage of development and other physiological aspects of the organism (9).

The findings of this study confirm the deleterious effect of prenatal stress during different gestational period (early as well as late) on the antioxidant systems in the brain of offspring. In comparison to the control group, the prenatally stressed offspring showed a marked decrease in activities of GSH-Rd and SOD in the brain and also decreased in the levels of reduced GSH, validating the suppressed antioxidant efficiency in combating the prenatal stress induced free radical damage. Prenatally stressed offspring also showed an increased basal corticosterone secretion and decreased adrenal ascorbic

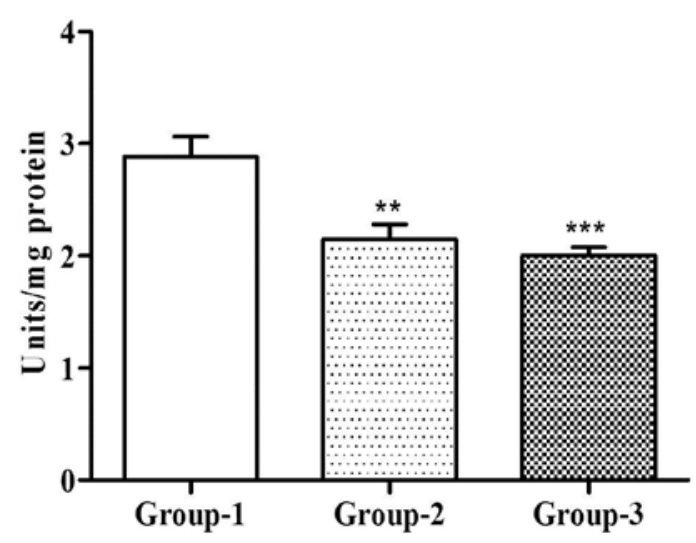

Figure 5: Brain Superoxide dismutase activity (U/mg protein) in rats. Values represent Mean \pm SEM from animal groups like; Group-1: control, Group-2: pups received prenatal stress during day1 to 10 and Group-3: pups received stress during day 11 till delivery ( $n=12$ per group). ${ }^{* *} P<0.001,{ }^{* * P}<0.01$ vs. Control (Group-1).

Table II: Percentage Change in the Antioxidant Activity in Rat Brain Homogenate, Serum Corticosterone and Adrenal Ascorbic Acid Level

\begin{tabular}{|l|c|c|}
\hline Serum Corticosterone & Group-2 & Group-3 \\
\hline Adrenal Ascorbic Acid & $+74.41 \%$ & $+106.2 \%$ \\
\hline GSH & $-27.93 \%$ & $-22.62 \%$ \\
\hline GSH-Rd & $-62.2 \%$ & $-59.88 \%$ \\
\hline SOD & $-53.29 \%$ & $-45.74 \%$ \\
\hline
\end{tabular}

'-' Sign indicates decrease, ' + ' Sign indicates increase over controls. acid level, our findings were consistent with earlier reports $(12,15,30)$. Zhu et al. (2004) investigated the effect of prenatal stress during middle and late gestation on neuronal loss and oxidative stress. They measured free intracellular $\mathrm{Ca}^{2+}$ and intracellular reactive oxygen species formation. However this study does not involve the estimation of antioxidant enzymes in neonatal brain. In the present study we have evaluated major antioxidant enzymes and also tested the effect of early gestational stress.

There is a variation in the hormonal level to stress during early and late gestation, i.e. increased basal corticosterone secretion was observed in the offspring who received prenatal stress during late gestation (106.2\%) than the offspring who received prenatal stress during early gestation $(74.41 \%)$ as mentioned in the Table II. But there was no variation observed in case of antioxidant status between prenatal stress during the early and late gestational period. This result indicates that prenatal stress during late gestation has a detrimental effect on developing HPA axis than prenatal stress during early gestation.

The reduced GSH content in the present experiment can be explained by: (i) The higher levels of free radicals that convert more reduced glutathione (GSH) to its oxidized form (GSSG) (21); and (ii) A decreased activity of glutathione reductase (3), the enzyme that regenerates reduced glutathione in a NADPH-dependent reaction. Dringen and Hirrlinger showed that the antioxidant glutathione is essential for the cellular detoxification of ROS in brain cells (4). In addition, the glutathione plays a vital role in the regulation of the redox state and prevention of the cell damage induced by oxidative stress (2).

Our data indicates that prenatal stress (during early as well as late) induced a significant inhibition of SOD and GSH-Rd activities. The possible reason for this finding could be the enhanced lipid peroxidation and the excess production of ROS. Increased fetal GC may cause increased activation of excitatory amino acid receptors and unregulated increases in intracellular $\mathrm{Ca}^{2+}$ concentrations, and consequently increased generation of oxidants and oxidative damage in brain. Prenatal stress caused an increase in the concentrations of the intracellular calcium and the production of ROS in the brain. $\mathrm{Ca}^{2+}$ influx plays a critical role in excitotoxicity, particularly via the NMDA receptors (1). The excess production of ROS, such as superoxide anion radical, hydroxyl radical, hydrogen peroxide, nitric oxide and peroxynitrate can oxidize key components of the cell including lipids, proteins, and nucleic acids (25). Brain is more vulnerable to the damage of ROS than are other organs because brain is enriched in oxidizable polyunsaturated fatty acid and redox-active metals, but antioxidant molecules are low (5).

A number of studies suggest that prenatal stress leads to higher fetal plasma cortisol and $\mathrm{CRH}$ (Corticotrophin Releasing Hormone) levels. This placental CRH and cortisol reaches the fetal brain and could influence the fetal brain development presumably by activating $\mathrm{CRH}$ receptors (24). 
Stress during pregnancy also reduces the expression and activity of the glucocorticoid barrier enzyme, 11 -HSD2 (11ß-hydroxysteroid dehydrogenase type 2$)$ in the placenta, leaving the fetus less protected (16). This may be associated with alterations in the offspring HPA axis activity as noted in our study (increased cortisol level and decreased adrenal ascorbic acid).

The exposure of prenatal stress to pups is more detrimental in two accounts: porous blood brain barrier and deficiency of endogenous glutathione system. Chronic prenatal stress exerted adverse effects on blood-brain-barrier (BBB) functional development; the mechanism includes increased transvascular transport mediated by caveolae (8). The stress effects upon BBB could affect important neural developing processes, such as neurogenesis, myelination, and synaptogenesis (22), since direct exposure to blood-borne products can induce neuronal and glial damage (26).

In conclusion, the present study demonstrated that both early and late gestational stress induced a significant decrease in activities of GSH-Rd and SOD and GSH levels female and male offspring brain. These results suggest that prenatal stress can result in elevated oxidant generation and oxidative damage to the neurons and that the oxidative neuronal damage may be due to the overproduction of $\mathrm{GC}$ in male and female offspring. Thus, we hypothesize that the formation of glutathione system during development is related to the changes in the levels of free radicals. Hence this knowledge is of importance as this will provide the basis for cognitive and behavioral disorders in children of mothers who work and function under duress and stressed conditions during pregnancy. So, it is important to support endogenous defines mechanism by exogenous antioxidant agents to prevent the oxidative stress related consequences in developing brain. Such studies in an animal model would throw more light on probable alternate therapeutic measures to combat the prenatal stress induced behavioural dysfunctions.

\section{ACKNOWLEDGEMENT}

Authors would like to thank the Indian Council of Medical Research (ICMR, IRIS ID NO. 2008-00150), New Delhi, for funding the present work.

\section{REFERENCES}

1. Attucci S, Clodfelter GV, Thibault O, Staton J, Moroni F, Landfield PW, Porter NM: Group I metabotropic glutamate receptor inhibition selectively blocks a prolonged $\mathrm{Ca}^{2+}$ elevation associated with age dependent excitotoxicity. J Neuroscience 112:183-194, 2002

2. Bounous G, Molson JH: The antioxidant system. Anticancer Res 23:1411-1415, 2003

3. Costagliola C: Oxidative state of glutathione in red blood cells and plasma of diabetic patients: In vivo and in vitro study. Clin Physiol Biochem 8:204- 210, 1991

4. Dringen R, Hirrlinger J: Glutathione pathways in the brain. J Biol Chem 384:505-516, 2003
5. Driver AS, Kodavanti PR, Mundy WR: Age-related changes in reactive oxygen species production in rat brain homogenates. Neurotoxicol Teratol 22:175-181, 2000

6. Ellman GL: Tissue sulfhydryl groups. Arch Biochem Biophys 82:70-77, 1959

7. Fameli M, Kitraki E, Stylianopoulou F: Effects of hyperactivity of the maternal hypothalamic-pituitary-adrenal (HPA) axis during pregnancy on the development of the HPA axis and brain; monoamines of the offspring. Int J Dev Neurosci 12:651-659, 1994

8. Gomez-Gonzalez B, Escobar A: Altered functional development of the blood-brain barrier after early life stress in the rat. Brain Research Bulletin 79:376-387, 2009

9. Halliwell B, Gutteridge JMC, (Eds): Free Radicals in Biology and Medicine. Oxford: Oxford Univ. Press, 1999

10. Kawamura T, Chen J, Takahashi T, Ichitani Y, Nakahara D: Prenatal stress suppresses cell proliferation in the early developing brain. Neuro Report 17:1515-1518, 2006

11. Liu J, Mori A: Stress, aging, and brain oxidative damage. Neurochem Res 24:1479-1497, 1999

12. Li X, Zhu Z, Chen W: The effect of different stage of prenatal stress on the spatial learning and memory of offspring rats. Chin J Behav Med Sci 12:604-606, 2003

13. Lowry $\mathrm{OH}$, Rosebrough NJ, Farr AL, Randall RJ: Protein measurement with the Folin phenol reagent. J Biol Chem 193:265-275, 1951

14. Maccari S, Morley-Fletcher S: Effects of prenatal restraint stress on the hypothalamus-pituitary-adrenal axis and related behavioural and neurobiological alterations. Psychoneuroendocrinology 32:10-15, 2007

15. Maccari S, Piazza P V, Kabbaj M, Barbazanges A, Simon H, Le Moal M: Adoption reverses the long-term impairment in glucocorticoid feedback induced by prenatal stress. J Neurosci 15:110-116, 1995

16. Mairesse J, Lesage J, Breton C, Breant B, Hahn T, Darnaudery M, Dickson SL, Seckl J, Blondeau B, Vieau D, Maccari S, Viltart O: Maternal stress alters endocrine function of the feto-placental unit in rats. Am J Physiol Endocrinol Metab 292:1526-1533, 2007

17. Marklund S, Marklund G: Involvement of superoxide anion radical in autooxidation of pyrogallol and a convenient assay of superoxide dismutase. Eur J Biochem 47:469-474, 1974

18. McIntosh LJ, Sapolsky RM: Glucocorticoids may enhance oxygen radical-mediated neurotoxicity. Neurotoxicology 17:873-882, 1996

19. Moron MS, Depierre JW, Mannervik B: Levels of glutathione, glutathione reductase and glutathione $S$-transferase activities in rat lung and liver. Biochem Biophys Acta 582:67-78, 1979

20. Lyle N, Bhattacharyya D, Sur TK, Munshi S, Paul S, Chatterjee S, Gomes A: Stress modulating antioxidant effect of Nardostachys jatamansi. Indian J Biochem Biophys 46:93-98, 2009 
21. Ou P, Nourooz-Zadeh J, Tritschler $\mathrm{HJ}$, Wolff S: Activation of aldose reductase in rat lens and metal-ion chelation by aldose reductase inhibitors and lipoic acid. Free Radic Res 25:337-346, 1996

22. Rao MS, Jacobson M: Developmental Neurobiology. Kluwer Academic/Plenum Publishers, New York, 2005

23. Sampath Madhyastha, Prabhu Latha V, Nayak Soubhagya R, Pai Mangala, Rajalakshmi, Prashanthi Madhyastha: Effect of Prenatal stress and serotonin depletion on postnatal serotonin metabolism in wistar rats. Iranian Journal of Pharmacology \& Therapeutics 7:71-77, 2008

24. Seckl JR., Holmes MC: Mechanisms of disease: Glucocorticoids, their placental metabolism and fetal 'programming' of adult pathophysiology. Nat Clin Pract Endocrinol Metab 3: 479-488, 2007

25. Shigenaga MK, Hagen TM, Ames BN: Oxidative damage and mitochondrial decay in aging. ProcNatl Acad Sci 91: 10771-10778, 1994
26. Rapoport SI: Sites and functions of the blood-brain barrier, in: SI Rapoport Ed, Blood-Brain Barrier in Physiology and Medicine. New York: Raven Press, 1976:43-86

27. Ward HE, Johnson EA, Salm AK, Birkle DL: Effects of prenatal stress on defensive withdrawal behavior and corticotropin releasing factor systems in rat brain. Physiol Behav 70: 359-366, 2000

28. Weinstock M: Alterations induced by gestational stress in brain morphology and behaviour of the offspring. Prog Neurobiol 65:427-451, 2001

29. Weinstock M, Matlina A, Maor Gl, Rosen H, McEwan BS: Prenatal stress selectively alters the reactivity of the hypothalamic-pituitary-adrenal system in the female rat. Brain Res 595:195-200, 1992

30. Zhongliang Zhu, Xia Li, Weina Chen, Yan Zhao, Hui Li, Cai Qing, Ning Jia, Zhuanli Bai, Jiankang Liu: Prenatal stress causes gender-dependent neuronal loss and oxidative stress in rat hippocampus. Journal of Neuroscience Research 78:837-844, 2004 